\title{
IS INTELECTUAL CAPITAL ANTECEDENT OF ENTERPRENEURSHIP ORENTATION
}

\author{
*Erol EREN \\ **Ebru Beyza KOCAPINAR \\ *Beykent University, Turkey \\ **Yeditepe University,Turkey
}

\begin{abstract}
Knowledge economy, which is characterized by the complex and dynamic competitive environments, knowledge-based resources (human capital, structural capital and market capital) represent the source of competitive advantage for the firms. In order to be able to seize the opportunities, make product and process innovations, be proactive in the market place, entrepreneurial firms have to reconfigure their intangible assets (Jantunen et al., 2005). The objective of this research is to empirically examine intellectual capital as a competitive knowledge resource of firms, initiate entrepreneurial climate that affect the organizational performance as financial and innovative outcomes. Recent conceptual models suggest that entrepreneurial orientation depends on the acquisition, the integration and the exploitation of knowledge (Hayton, 2002). According to this conceptual framework a model is developed to examine the direct and the mediator relation between intellectual capital and entrepreneurial orientation. To investigate the stated relationships data will be collected from Turkey's Top 500 Industrial Enterprises. Questionnaires are prepared by the researchers based on the measurement instrument used by Subramaniam \&Youndt (2005), Bontis (1998) and Dess \& Lumpkin (1996) after the preliminary survey that is done for the reliability and validity analysis of the measurement instrument which is modified for cultural differences and for the purposes of this study, will be distributed via mail and the internet site. Data will then be analyzed by the SPSS statistical program.
\end{abstract}

Keyword: Intellectual Capital, Entrepreneurship Orientation, Financial and Innovation Performance.

\section{INTRODUCTION}

Fundamental changes have been wrought in the global economy which are changing the basis of firm level competitive advantage, and with it the functions of management. The decreased cost of information flow increases in the number of markets, the liberalization of product and labor markets in many parts of the world, and the deregulation of international financial flows is stripping away many traditional source of competitive differentiation and exposing a new fundamental core as the basis for wealth creation (Teece, 2000, p.3).

With the shift from seller's markets to a buyer's markets and the development of the resource- and knowledge-based view of firms, intellectual capital has been identified as a key resource and driver of organizational performance and value creation (Itami, 1987; Teece 200; Nahapiet and Ghoshal 1998). According to the resourced-based view of the firm, sustainable competitive advantage is derived from control of unique and inimitable knowledge-based resources (Barney, 1991). Teece (1998) claimed that a competitive advantage of firms in today's economy does not result from its market position but difficult-to-replicate the knowledge-based assets and the manner they are devel- 
oped (Marr and Ross, 2005). Organizational and technological capabilities offer sustainable competitive advantages to a firm in rapidly changing markets by recognizing changes and understanding their consequences and reconfiguring its firm-specific assets base. In order to be able to seize the opportunities, make product and process innovations, and be proactive in the market place, entrepreneurial firms have to understand and reconfigure their intangible assets (Jantunen et al., 2005).

\section{Intellectual Capital}

Organizational knowledge is an important bundle of intangible resources that can be the source of a sustainable competitive advantage (Wiklund and Shepherd, 2003). Prior research conceptualizes intellectual capital as the sum of all knowledge and knowing capabilities that can be utilized to give a company competitive advantage (Nahapiet and Ghoshal, 1998; Stewart,1991). In 1991 Tom Stewart was the first researcher who defined intellectual capital as "the sum of everything everybody in your company knows that gives you a competitive edge in your marketplace" (Stewart, 1991). After Stewart, other researchers and practitioners try to explain the terms in different ways. Hudson (1993) defined the IC as a personal asset of individuals, a combination of genetic inheritance, education, experience and attitude about life and business (Bontis, 1998). Nahapiet and Ghoshal (1998) use the term intellectual capital to refer to the knowledge and knowing capability of a social collective, such as an organization. On the other hand, Brooking (1997) used the intellectual capital term in explaining the combined intangible assets which enable the company to functions and broaden definition of the IC market assets, the human centered assets, the intellectual property assets and the infrastructure assets. Marr and Schimuma (2001) pointed out that 'IC is the group of knowledge assets that are attributed to an organization and most significantly contribute to an improved competitive position of this organization by adding value to defined key stakeholders'.

All intellectual capital researchers agree that it is not a unidimensional construct; rather it resides at various levels like individual, network and organizational one. So, intellectual capital is not constrained to the knowledge held by individuals, but also includes knowledge stored within organizational database, business processes, systems and relationships (Youndt \& Subramaniam, 2004:335). Generally the literature has identified three sub-dimensions that constitute the concept of intellectual capital: human capital, structural capital and customer capital.

\section{Human Capital+ Structural Capital + Customer Capital = Intellectual Capital}

Human capital represents the individual knowledge stock of an organization by its employees (Bontis ,2001; Youndt et al, 2004) This knowledge resources can be skills, experience, expertise, ideas, knowledge, competencies, abilities and values of employees. According to Skandia (1996), human capital is accumulated value of investments. However, Hudson (1993) claimed that combination of genetic heritance, education, experience, attitude about life and business can be defined as human capital on individual level. Human capital is important for entrepreneurial organizations because it is a source of innovation and strategic renewal, whether it is from brainstorming in a research lab, daydreaming at the office, throwing out old files, re-engineering new processes, improving personal skills or developing new leads in a sales little black book (Bontis, 1998:65).

Structural capital is defined as the knowledge that stays within the company at the end of working day. It represents institutionalized knowledge and codified experience stored in structure, systems, applications, procedures, databases, patents, trademarks, manuals, policies, vision and values (Hall, 1992; Itami, 1987; Bontis, 1996; Stewart, 1997). Bontis (1998) argued that an individual can have a 
high level of intellect, but if the organization has poor systems and procedures by which to track his or her actions, the overall intellectual capital will not reach its fullest potential.

Last dimension of the IC is customer capital, the value that results from an organization's relationship with customers (Chang \& Tseng, 2005). The main idea of customer capital is the knowledge embedded in the marketing channels and customer relationships that an organization develops through the course of conducting business which will enhance its competitive advantage (Bontis, 1998; Bontis et al.,2000; Bontis and Fritz-enz, 2002). Reichhed (1993) found that a 5 percent increase in customer retention resulted in an increase in average customer lifetime value of between 35 and 95 percent, leading to significant improvements in company profitability. Additionally, Holmlund and Kock (1996) pointed out that long term relationships with customer allow access to detailed and useful knowledge about the customers. Thus, new knowledge and new ideas can be turned into to new products and services which are the source of innovation (Tsan \& Chang, 2005:290).

Many resource-based view scholars like Prahalad (1996), Grant (1996), Barney (1991) have argued that the intangible assets are the pre-eminent drivers of competitive advantage. The main reason under this assumption is difficult to replicate intangible assets as opposed to physical or tangible assets (Barney, 1991; Dierickx and Cool, 1989; Zander and Kogut, 1995). Especially, the knowledge-based view of the firm posits that tacit and contextualized knowledge bases due to their inimitability, help facilitate superior performance (Youndt et al. 2004).

Over the past decade researchers have started to emphasize the importance of intellectual capital. Academics have traditionally been very interested in how intangible assets reflect on the performance of firms. Accordingly, a recent surge of writings and empirical studies examined the development, usage, and performance effects of intellectual capital (Edvinsson and Malone, 1997; Gupta and Govindarajan, 2000; Stewart, 1997; Tsai and Ghoshal, 1998). Edvinsson and Malone (1997), Bontis and his friends' (1998), Youndt et al. (2004), all researches found that human, structural and customer capital have a significant effect on organization performance. However Bontis and friends (2000) studies in Malaysians' companies have shown that intellectual capital has a significant and substantive relationship with business performance regardless of industry sector. On the other hand, Subramaniam and Venkatraman (2001), empirically demonstrated how the tacit knowledge contributes to the development of superior organizational capabilities, which, in turn, increase performance. Hence, the knowledge-based view of the firm provides strong rationale as to intellectual capital's role in enhancing organizational performance (Youndt et al., 2004:344).

\section{Entrepreneurial Orientation}

Entrepreneurship has been an interest to academics and practitioners for the past three decades. The term 'entrepreneur' has been used by Cantillon in 1755, to describe an individual with foresight and ingenuity who, within the parameters of economic markets, are willing to embrace uncertainty and engage proactively in pursuits of profit (Küçük,2005). The modern concept of entrepreneurship in which much of the academic research is grounded was articulated by Schumpeter (1934), who saw an entrepreneur as visionary and innovator, making new combination of resources in an effort that could lead to "creative destruction" of existing combinations as a new product, process or market that replaces the old (Küçük,2005).

The concept of entrepreneurship has been studied from both individual and corporate perspectives (Covin and Slevin, 1991, Naman Slevin, 1993, Dess et al., 2003). In 1980s, most of the entrepreneurship researches focused on individual as an entrepreneur. However, researchers pointed out that 
individual trait approach did not lend itself to measurability, replication and generalizability (Covin \& Slevin, 1994). Academics started to investigate firm behavior instead of individual characteristics which can understandable, measurable and transferable to organization strategies. Firm level entrepreneurial behavior can be managed through the creation of particular organizational strategies, structures, systems and cultures (Covin and Slevin ,1991).

Entrepreneurial orientation first defined by Miller. According to Miller (1983) entrepreneurial firm is one that 'engages in product market innovation, undertakes somewhat risky ventures, and is first to come up with proactive innovations, beating competitor to the punch" (1983:771).On the other hand Lumpkin and Dess (1996), used "entrepreneurial orientation" to refer to the strategy making processes, methods and styles of firms that engage in entrepreneurial activities. As such, it reflects how a firm operates rather than what it does (Lumpkin and Dess, 1996). Underlying an entrepreneurial orientation is a tendency to pursue the creation and acquisition of new knowledge and the integration of new knowledge and capabilities with existing resources in the form of new combinations (Hayton, 2005).

Miller (1983) conceptualizes entrepreneurial orientation in three dimensions: proactiveness, innovation and risk taking. Additionally Lumpkin and Dess (1996) added two more dimensions that include a propensity to act autonomously and aggressively toward competition.

Organizational innovation represents a significant change in the organization, whether a response to changes in its internal or external environment or as preemptive action to influence an environment (Damanpour, 1991). Innovation concept is the most researched term in both individual and organizational entrepreneurship studies. Schumpeter (1934) was the first writer who used innovation in explaining entrepreneurship. Lumpkin and Dess (1996, p. 142) defined innovation dimension as "the tendency of a firm to engage in and support new ideas, novelty, experimentation and creative processes that may result in new products, services or technological processes. Beside Covin and Slevin proposed innovation as "the extensiveness and frequency of product innovation and the related tendency toward technological leadership (1991,p.10).

Risk, as the possibility of loss, may be viewed as an inherent characteristic of innovativeness, new business formation and aggressive or proactive actions of existing firms (Antoncic \& Hisrich, 2003, p.17). Risk taking dimension is the earliest characteristic of entrepreneur. Miller and Friesen (1978) used risk taking as "the degree to which managers are willing to make large and risky resource commitments-i.e., those which have a reasonable chance of costly failures (Dess \& Lumpkin, 1996). It largely reflects the organization's willingness to break away from the tried-and true and venture into unknown (Wiklund, 2003). Thus in organizational risk taking behavior, the management will take risk with regard to investment decisions and strategic actions in uncertainty conditions (Covin and Slevin, 1991).

Most academicians used proactiveness dimension in explaining organizational posture of anticipating and acting on future wants and needs in the marketplace, that create a first mover advantage, to rivals (Wiklund, 2003). So then proactiveness is critical for entrepreneurial firms because it suggest a forward looking perspective that is along with innovative or new venturing. Additionally Miller and Friesen (1978) claimed that proactive firms are the one that is quickest to innovate and the first to introduce new products or services.

Competitive aggressiveness is the last dimension of entrepreneurial orientation which refers to a firm's rivals propensity to directly and challenge its competitors to achieve entry or improve posi- 
tion, that is, to outperform industry rivals in the marketplace (Lumpkin \&Dess, 1996:148). According to Covin and Covin (1990) competitive aggressiveness is managerial disposition in explaining organizational willingness and the desire to take on and dominate the competitors. Although same researcher thought there is no need to separate proactiveness and competitive aggressiveness. (Guth and Ginsberg, 1990; Zahra,1991), Lumpkin (1998) and his colleagues (1997), empirically explained that the two dimension can be distinct, they tend to vary independent. They stated that proactiveness relates to pioneering in seizing market opportunities, while competitive aggressiveness is deal with an aggressive organizational relationship to its competitors (Antoncic \& Hisrich, 2003).

In strategy literature, organizations that have an entrepreneurial orientation have been found to have significant, positive performance differentials over other firms (Lumpkin \& Dess, 1996; Covin \& Slevin, 1996; Ireland \& Hitt, 2000; Zahra and Covin, 1995; Zahra et. al. 1999; Wiklund and Shepherd, 2005). But on the other side the empirical results are mixed. Lee and his friends study's (2001) showed that only weak evidence of a positive relationship between entrepreneurial orientation and the start-up's performance, whereas Slater and Narver (2000) found no relationship at all, with business profitability. Additionally Zahra and Garvis (2000) suggest that entrepreneurial activities enhance overall and foreign profitability and revenue growth, and that entrepreneurship moderates the relationship between environmental hostility and performance, to the advantage of the latter (Jauntan, 2007:226).

Lumpkin and Dess (1996) in their conceptual model proposed that factors internal and external to the firm may moderate the relationship between EO and performance. Empirically, research has found that the effect of EO on performance may be diverse in different types of environments. Besides Wiklund and Shepherd (2003) suggest that an entrepreneurial orientation enhances the relationship between a firm's knowledge-based resources and its performance. Entrepreneurial orientation supports sustained competitive advantage through the continuous generation and exploitation of new sources of knowledge. Therefore, OE can have significant impact upon organizational financial and market performance (Hayton 2005).

According to entrepreneurship academics EO refers to a firm's strategic orientation, capturing specific entrepreneurial aspects of decision-making styles, methods and practices so it reflects how firm operates rather than what it does (Lumpkin and Dess, 1996). Wiklund and Shepherd (2003) pointed out that EO clarifies how a firm is organized knowledge resources in order to discover and exploit market opportunities and product innovations. Moreover, they argued that EO captures a firm's organization toward entrepreneurship and enhance other firm resources. On the other hand Zahra, Nielsen and Bogner (1999), suggested that knowledge integration and learning may be a central element in theoretical explanation of why EO is positively associated with firm performance. If this is the case, then an important set of resources that are expected to be associated with entrepreneurial orientation are the intellectual capital assets that a firm controls (Hayton, 2002).

Based on the literature review, the research model in, Figure 1 is developed to measure extended organizational resource as intellectual capital which is antecedent to a firm's ability behaves entrepreneurially.

\section{$H_{1}$ : Intellectual capital has a positively related to firm performance.}

\section{$\mathrm{H}_{2}: \mathrm{EO}$ mediates the relation between intellectual capital and firm performance}




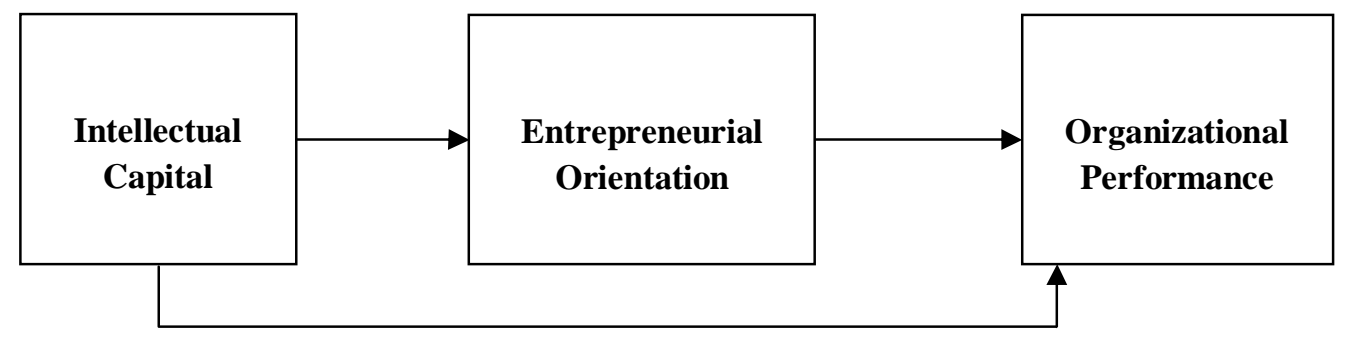

Figure 1: The Proposed Research Model

\section{METHODOLOGY}

\section{Sample}

The goal of this study is to empirically explore the association between intellectual capital and entrepreneurial orientation among Turkish companies. The common point of the international studies in both intellectual capital and entrepreneurial orientation is large firms with large sample sizes (Bontis, 2002). Because of not having enough resources, small and middle size enterprises could not start entrepreneurial applications. Thus the participants of the study will be chosen from the list of Turkey's Top 500 Industrial Enterprise obtained from The Istanbul Chamber of Industry.

The focus on middle managers is consistent with the growing recognition of the key role these managers play in promoting or stifling corporate entrepreneurship efforts (Burgelman, 1983b; Floyd and Woolridge 1992, 1994; Pinchott 1985; Nonaka and Takeuchi, 1995). On the other hand information asked in both intellectual capital and entrepreneurial orientation questions are very specific that only middle managers can answer, so respondents are chosen from middle managers.

\section{Instruments}

A measurement scale is adopted from prior studies. All instruments were first translated into Turkish, and then these Turkish versions were again translated into English by researchers, and necessary modifications were made accordingly. All scales used a five-point Likert-type scale, ranged from 5 "totally agree" to 1 "totally disagree"

\section{Intellectual Capital Scale}

After examining previous studies, according to the framework, new measurement scale was developed by researches. Intellectual capital was measured with three dimension human capital, structural capital and customer capital. These 17 questions were taken from by Subramaniam \& Youndt (2005), Bontis (1998), Chen, Zhu Xie (2004), Hayton (2005), Pablo's (2003) and Hall (1993). Intellectual Capital Questionnaire, a five-point Likert-type scale, with anchors of "totally agree" to "totally disagree" is used to collect responses.

\section{Entrepreneurial Orientation Scale:}

According to Dess and Lumpkin, (1996) the five dimension which are autonomy, innovativeness, risk taking, proactiveness and competitive aggressiveness, is useful for characterizing and distinguishing the key entrepreneurial processes in firm's entrepreneurial orientation. Miller was the first academician who developed the scale but Dess and Lumpkin $(1996,1998)$ improved the scale. In this 
study Entrepreneurial orientation divided four sub-dimensions and was measured by Dess and Lumpkin's (1996) seventeen -item scale.

\section{Performance Scale}

In this study, two performance criteria are used to measure the organizational performance which is financial performance and market performance. Organization financial performance scale is integrated from Lumpkin \& Dess (1996) ;Wiklund \& Shephard (2003);and market performance scale is adapted from Antoncic (2000); Zahra (1993); Hagedoorn \& Cloodt (2003) performance criteria's. According to Wiklund and Shepherd (2003) performance is multidimensional and performance comparisons with competitors reveal important information. As a result middle managers were asked to compare the development of their own firms over 3 years relative to their industry competitor for 16 different dimension of performance; like return on sales, profitability per customer, revenue growth, return on investment, profit growth, return on assets, market new products before competitors, rate of new product introduction into market, number of new product /process add by company, your company spending on new product development, number of patent and patent citations. Organizational performance questionnaire, a five-point Likert-type scale, with anchors of "totally high over the industry average" to "totally low from the industry average" was used to collect responses.

\section{Data Collection and Procedure}

First, pilot study was conducted to 120 employees from 20 companies to analyze the reliability of the instruments. After the pilot study a cover letter and questionnaires were mailed directly to the middle and top managers in each of the 500 organizations' factories and headquarters. After five weeks because of the low return responses, a new cover letter and same questionnaires were sent to non-respondents. However out of 1000 questionnaires distributed in Turkey's Top 500 Industrial Enterprise 376 were returned which yielded a return rate of $37 \%$.

\section{RESULTS:}

\section{Factor Analyses}

The factor structure of the data gathered by Intellectual Capital scale was analyzed using principal components analysis with varimax rotation. This analysis yielded three factors with Eigen value over 1.00 that explained $65,88 \%$ of the total variance. The IC subscale has 17 items. After the first factor analysis, three factors emerged and three item was eliminated. When the factor analysis was run again three factors emerged, labeled as "structural capital," "human capital" and "customer capital " (Table 1).

The same procedure was repeated for the data collected by EO instrument and this analysis also yielded four factors explaining the $72,4 \%$ of total variance. The seventeen items measuring structure were loaded on four factors after the first factor analysis. No item was eliminated. The factors were labeled as "Proactiveness", "Risk taking", "innovativeness" and "competitive aggressiveness" (Table 2).

The sixteen items measuring performance were loaded on two factors after the first factor analysis. Four item had to be eliminated because of low levels of reliability. When the factor analysis was run again, two factors that emerged labeled as "financial performance" and "innovation performance" (Table 3) 
Table 1. Reliability and Factor Analysis of Intellectual Capital

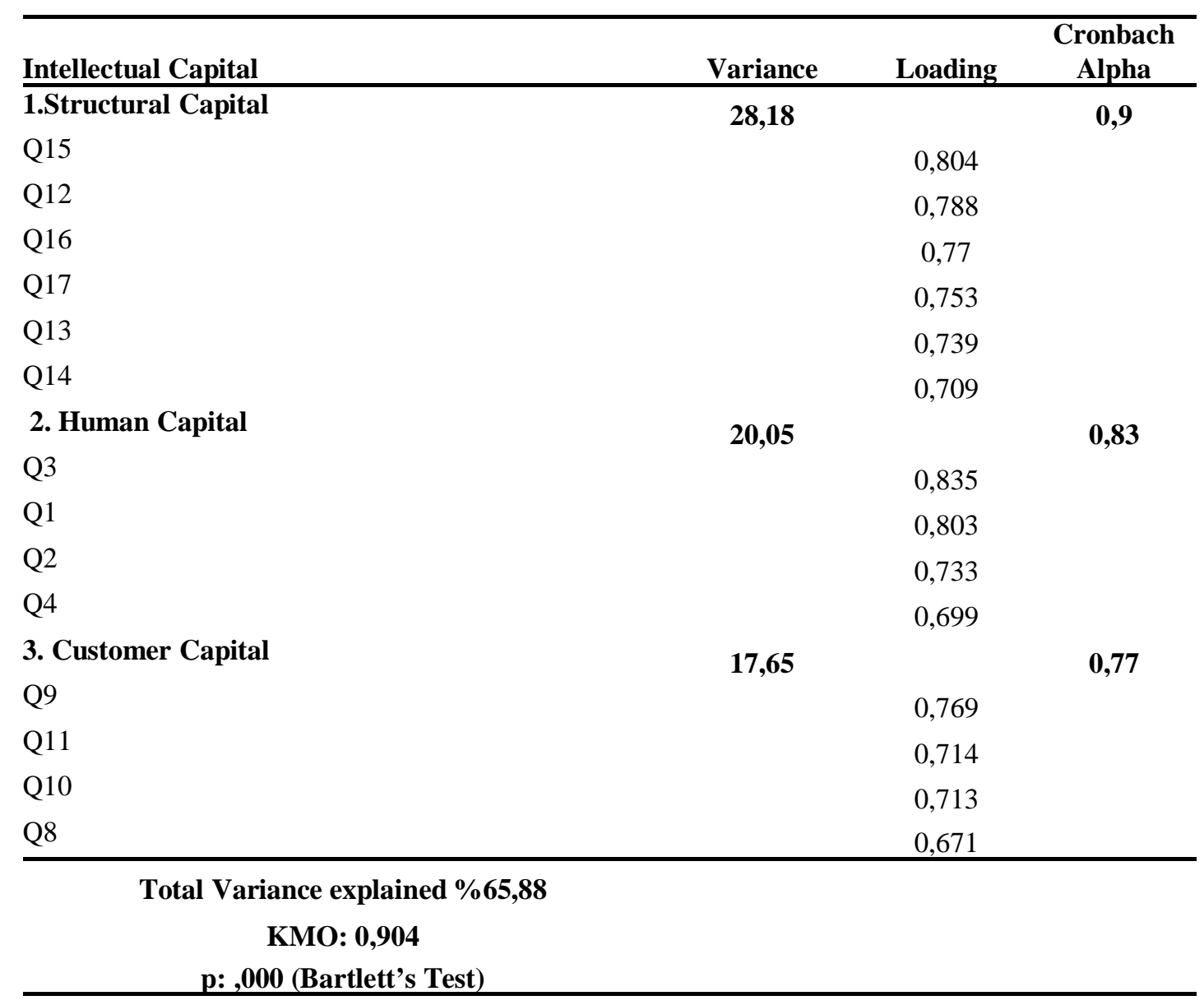


Table 2. Reliability and Factor Analysis of Entrepreneurial Orientation

\begin{tabular}{lccc}
\hline Entrepreneurial Orientation & Variance & Loading & Cronbach Alpha \\
\hline 1.Proactiveness & $\mathbf{2 1 , 6 6}$ & & $\mathbf{0 , 9}$ \\
Q7 & & 0,869 & \\
Q8 & & 0,815 & \\
Q9 & & 0,762 & \\
Q6 & & 0,754 & \\
Q10 & $\mathbf{2 0 , 0 1}$ & & \\
2. Risk Taking & & 0,603 & $\mathbf{0 , 8 6}$ \\
Q3 & & 0,828 & \\
Q2 & & 0,767 & \\
Q5 & & 0,757 & \\
Q4 & & 0,717 & \\
Q1 & $\mathbf{1 7 , 5 1}$ & & $\mathbf{0 , 8 9}$ \\
3. Innovativeness & & 0,884 & \\
Q16 & & 0,845 & \\
Q15 & & 0,709 & \\
Q14 & & 0,679 & \\
Q17 & $\mathbf{1 7 , 8 6}$ & & $\mathbf{0 , 7 6}$ \\
4. Competitive Aggressiveness & & 0,831 & \\
Q12 & & 0,78 & \\
Q11 & & 0,723 & \\
Q13 & &
\end{tabular}

Total Variance explained \%\% 72,04

KMO: 0,902 p: ,000 (Bartlett's Test)

The relationships between dependent and independent variables were tested by hierarchical regression analyses. As can be seen on Table 4, a positive relationship between intellectual capital and both innovation and financial performance was observed and $\mathbf{H}_{\mathbf{1}}$ was accepted.

As can be seen in the research model, EO was assumed to mediate the relationship between intellectual capital and organizational performance. To test mediating effect of EO, three stages multiple regression method was used (Baron and Kenny, 1986). In this method, first the effect of IC (independent variable) on EO (intervening variable) was analyzed. Second, the relationship between independent and dependent variables was tested. If the results in both levels were significant, in the third level independent and intervening variables were tested together to understand their effects on dependent variables. If the effect of independent variable on dependent variable was insignificant or has lower coefficient (beta), this variable can be discussed as an intervening variable. The result of the regression analysis of intervening variable was presented in Table 4 and also $\mathbf{H}_{\mathbf{2}}$ was accepted. 
Table 3. Reliability and Factor Analysis of Performance

\begin{tabular}{lccc}
\hline Organizational performance & Variance & Loading & $\begin{array}{c}\text { Cronbach } \\
\text { Alpha }\end{array}$ \\
\hline 1. Financial Performance & $\mathbf{3 8 , 3 3}$ & & $\mathbf{0 , 9 4}$ \\
Q7 & & 0,867 & \\
Q2 & 0,845 & \\
Q9 & 0,822 & \\
Q10 & 0,82 & \\
Q8 & & 0,815 & \\
Q4 & & 0,79 & $\mathbf{0 , 9 2}$ \\
2. Innovation Performance & & \\
Q12 & $\mathbf{3 7 , 4 4}$ & 0,875 & \\
Q13 & & 0,852 & \\
Q11 & & 0,812 & \\
Q15 & & 0,793 & \\
Q14 & & 0,773 & \\
Q16 & & 0,768 & \\
\hline
\end{tabular}

Total Variance explained \% 75,79

KMO: 0,925

p: ,000 (Bartlett's Test)

Table 4: The Three Stages Multiple Regression Analysis of Entrepreneurial Orientation

\begin{tabular}{lll}
\hline First Stage Variables & Entrepreneurial Orientation & \\
\hline Intellectual Capital & $.602^{* * * *}$ & \\
$\mathbf{R}^{2}$ & .362 & \\
Adjusted $\mathbf{R}^{2}$ & $.359^{* * *}$ & \\
F Value of Model & $105.544^{* * *}$ & Financial Performance \\
Second Stage Variables & Innovation Performance & $.26^{* *}$ \\
\hline Intellectual Capital & $.299^{* * *}$ & .068 \\
$\mathbf{R}^{2}$ & .089 & $.063^{* * *}$ \\
Adjusted $\mathbf{R}^{2}$ & $.084^{* * *}$ & $13.535^{* *}$ \\
F Value of Model & $18.244^{* * *}$ & Financial Performance \\
Third Stage Variables & Innovation Performance & .089 \\
\hline Intellectual Capital & .134 & $.285^{* * *}$ \\
Entrepreneurial Orientation & $.275^{* *}$ & .120 \\
$\mathbf{R}^{2}$ & .137 & .110 \\
Adjusted $\mathbf{R}^{2}$ & .128 & $.120^{* * *}$ \\
F Value of Model & $137^{* * *}$ & $12.576^{* * *}$ \\
F Value of Model & $14.739^{* * *}$ & \\
\hline Independent Variables: Intellectual Capital, Entrepreneurial Orientation \\
Dependent Variables: Innovation Performance, Financial Performance \\
${ }^{*}$ p $<0,05 * * p<0,01 * * * p<0,001$ & &
\end{tabular}




\section{DISCUSSION AND CONCLUSIONS}

The goal of the study is to understand the effect of entrepreneurial orientation on organizational performance. In this relationship, the intellectual capital is taken as an antecedent of entrepreneurial orientation to explore the impact of organizational knowledge-resource on entrepreneurial orientation.

Intellectual capital is the knowledge-resources that provide sustainable competitive advantage to the firms. Prior empirical studies have been found that human, structural and customer capital have a significant positive effect on organization performance, thus the results of regression analysis of this research also shows the positive relationship between the intellectual capital and the financial and the innovation performance in Turkish Companies.

Recent conceptual models suggest that entrepreneurial orientation is dependent upon the acquisition, integration and exploitation of knowledge. Last decade strategy researches consistently suggest that internal organizational factors, such as organizational support for new ideas and projects, participation in decision making, tolerance of risk taking play a role in encouraging corporate entrepreneurship. point out that the factor that outside the organization and within the organization interacts, challenging the managers to respond creatively and act in innovative ways. Then it is reasonable to expect that organizational knowledge is an important resource that supports a firm's entrepreneurial behavior. This study's empirical result is consistent with arguments. According to the multiple stage regression analysis, entrepreneurial orientation was found as a mediating variable between intellectual capital and organizational performance. In first level intellectual capital and entrepreneurial orientation was tested. The regression analysis results for intellectual capital on entrepreneurial orientation indicate that there is a positive and significant relationship between intellectual capital and entrepreneurship orientation. In the second level of three stages multiple regression analysis, the intellectual capital effect on organizational performance has been analyzed. Results indicated that; intellectual capital has significant effects on innovation performance and financial performance. In the third level, intellectual capital and entrepreneurial orientation was taken together. As a result, entrepreneurial orientation indicated significant results; entrepreneurial orientation was found as an mediating variable between intellectual capital and organization innovative and financial performance. Thus, entrepreneurship creates and leverage knowledge within the firms and intellectual capital, feed the entrepreneurial process knowledge which is the basis source of entrepreneurial initiatives.

Like all studies, the study has limitations primarily that firms included in our sample were from Turkey's Top 500 Industrial Enterprise. However, in future studies, all type of companies (like small or medium) or different industries (like service industry) would improve comparability between types and industries. Also it would give more detailed knowledge for researchers. On the other hand, to monitor the different culture and country applications of the model, future researchers could use cross-cultural comparability. 


\section{REFERENCES}

Antoncic, B. ve Hisrich, R.D., (2001) "Intrapreneurship: Construct Refinement and Cross-Cultural Validation," Journal of Business Venturing, 16, 495-527.

Antoncic, B. ve Hisrich, R.D., (2004) "Corporate Entrepreneurship Contingencies and Organizational Wealth Creation," Journal of Management Development, 23(6), 518-550.

Barney, J.B. (1991), Firm Resource and Sustained Competitive Advantage, Journal of Management ,17(1), 99-120.

Baron, M. R. \& Kenny, D. A. (1986). The Moderator-Mediator Variable Distinction in Social Psychological Research: Conceptual, Strategic, and Statistical Considerations. Journal of Peronality and Social Psychology, 51 (6), 1173-1182.

Bontis N., Chua, W. and S. Richardson. (2000). Intellectual Capital and the Nature of Business in Malaysia, Journal of Intellectual Capital, 1(1), pp.85-100.

Bontis N., Keow W. C. and Richardson S. (2000), Intellectual capital and business performance in Malaysian industries, Journal of Intellectual Capita, 1.

Bontis, N., (1999) Managing Organizational Knowledge by Diagnosing Intellectual Capital: Framing and Advancing the State of the Field, International Journal of Technology Management, 18.

Bontis, N., (2001) Assesing Knowledge Assets: A Review of the Models Used to Mesaure Intellectual Capital , International Journal of Management Reviews, 3( 1).

Bontis, N., (2004) National Intellectual Capital Index: A United Nations Initiative for the Arab Region, Journal of Intellectual Capital, 5(1).

Bontis, N., Keow, W.C.C., Richardson, S., (2002) Intellectual Capital and Business Performance in Malaysian Industries, Journal of Intellectual Capital,1(1).

Bontis, Nick and Jac Fitz-enz. (2002) Intellectual Capital ROI: A causal map of human capital antecedents and consequents, Journal of Intellectual Capital, 3( 3), pp.223-247

Bontis, Nick. (1998). Intellectual Capital: An exploratory study that develops measures and models, Management Decision, 36(2), pp.63-76

Brooking A.(1997), The Management of Intellectual Capital, Long Range Planning, 30(3), pp.364365 .

Chang A and Tseng C. (2005), Building customer capital through relationship marketing activities: The case of Twainese multilevel marketing companies, Journal of Intellectual Capital, . 6(2), pg. 253-266.

Chang A. \& Tseng C., (2005), Building customer capital through relationship marketing activities: The case of Tawanese multilevel marketing companies, Journal of Intellectual Capital, 6(2), pp. 253 $-266$.

Choo, C. W. and Bontis N. (2002), The Strategic Management of Intellectual Capital Organizational Knowledge, Oxford University Pres, NewYork, NY. 
Covin, J.G. ve Slevin, D.P. (1991). "A conceptual Model of Entrepreneurship as Firm Behavior,". Entrepreneurship Theory and Practice 16(1):7-25.

Damanpour, F. (1991). "The Adoption of Technological, Administrative, and Ancillary Innovations: Impact of Organizational Factors,” Journal of Management, 13(4), 675-688.

Dess G. \& Lumpkin G., Covin G.(1997), Entrepreuneurail strategy making and firm performance: tests of contingency and configurational model. Strategic Management Journal, 18(9), pp.677-95.

Dierickx I. and Cool K.(1989).Assets stock accumulation and sustainability of competitive advantage. Management Science 35, pp.1504-1511

Edvinsson, L. and Malone, M. S. (1997). Intellectual Capital: Realizing tour Company's True Value by Finding its Hidden Brainpower. New York: Harper Business.

Floyd, S. W., \& Wooldridge, B. 1999. Knowledge creation and social networks in corporate entrepreneurship: The renewal of organizational capability. Entrepreneurship Theory and Practice, 23(3): 123-143,

Guth, W.D. ve Ginsberg, A. (1990). "Guest Editors' Introduction: Corporate Entrepreneurship," Strategic Management Journal, Summer, 11, 5-15

Hall R.(1992), The strategic analysis of intangible resources, Strategic Management Journal, 13, pp.371-386.

Hayton C. J.(2005), Promoting corporate entrepreneurship through human resource management practices: A review of empirical research, Human Resource Management Review, 15 ss. 21-41.

Hayton J.C (2002), The effect of intellectual capital on EO in high technology new venture http://www.sveiby.com/Portals/0/articles/IntellectualCapital.html

Hudson W.(1993), Intellectual Capital: How to Build It, Enhance It, Use It. New York: Wiley

Itami H.,(1987), Mobilizing Invisible Assets. Boston: Harvard University Press.

Jantunen A., Puumalainen K. Saarenketo S., Kylaheıko K. (2005),Entrepreneurial Orientation, Dynamic Capabilities and International Performance,Journal of International Entrepreneurship 3, pp.223-243,

Lumpkin, G.T. \& Dess, G.G. (1996).Clarifying the entrepreneurial orientation construct and linking it to performance. The Academy of Management Review. 21(1), pp.135-172.

Marr B., and Schimuma G., (2001), Measuring And Managing Intellectual Capital And Knowledge Assets In New Economy Organizations. Handbook of Performance Measurement, London.

Marr B.; Ross G. (2005), A Strategy Perspective on Intellectual Capital Perspective on Intellectual Capital.

Marr, B., Gupta, O., Pike, S., Ross, G., (2003), Intellctual Capital and Knowledge Management Effectiveness", Management Decision, 41(8).

Miller, D., (1983), The correlates of entrepreneurship in three types of firms, Management. Science. 29, pp.770-791. 
Morris, M.H. and Sexton, D.L. (1996). The concept of entrepreneurial intensity: Implications for company performance, Journal of Business Research, Vol. 36, No. 1, 5-13.

Nahapiet, J. \& S.Ghoshal. (1998). Social capital, Intellectual capital and the organizational Advantage, Academy Of Management Review 23(2), pp.242-266.

Naman, J. L. ve Slevin, D. P. (1993). "Entrepreneurship and the Concept of Fit: A Model and Empirical Tests," Strategic Management Journal, 14, 137-154.

Narver, John C. and Stanley F. Slater. (1990), The Effect of a Market Orientation on Business Profitability, Journal of Marketing, 54, pp.20-35.

Orhan Küçük (2005), Giripimcilik ve Küçük Ýpletme Yönetimi, Seçkin Yayýncýlýk, Ankara 2ed.

Patricia Ordonez de Pablos (2002), Evidence of intellectual capital measurement from Asia, Europe, and the Middle East, Journal of Intellectual Capital,3(3), pp. 287-302.

Pennings J. M. \& Harianto F.(1992), Technological networking and innovation implementation, Organization Science 3 (3), pp.356-383.

Skandia (1996), Power of Innovation: Intellectual Capital Interim Annual Report Supplement.

Stewart, T.A., (1997), Intellectual Capital: The New Wealth of Organizations, New York: Doubleday.

Storey J. (1995), HRM: still marching on, or marching out?, in Storey J.(ed.) Human Resource Management: A Critical Text. London: Routledge.

Subramaniam m. \& Youndt M.A. (2005) The Influence of Intellectual Capital on the Types of Innovative Capabilities The Academy Of Management Journal

Subramaniam, M. and Venkatraman, N. (2001). "Determinants of Transnational New Product Development Capability: Testing the Influence of Transferring and Deploying Tacit Overseas Knowledge", Strategic Management Journal, 22, 359-378.

Teece, D. J. (2000), Managing Intellectual Capital: Organizational Strategic, and Policy Dimentions, Oxford University Press, Oxford.

Tsai, W. and Ghoshal, S. (1998), Social capital and value creation: the role of ingraining networks, Academy of Management Journal, 41, pp.464-478

Tsan W., \& Chang C. ,(2005), Intellectual capital system interaction in Taiwan, Journal of Intellectual Capital, 6 (2), pp. 285-298.

Wiklund, J. and Shepherd D., (2003),Knowledge-Based Resources, Entrepreneurial Orientation, and the Performance of Small and Medium-Sized Businesses, Strategic Management Journal 24 (13),pp.1307-1314.

Wiklund, J. ve Shepherd, D. (2005). "Entrepreneurial orientation and small business performance: a configurational approach," Journal of Business Venturing, 20, 71-91.

Wright P.M., McMahan G.C., and McWilliams A.,(1994), Human resources and sustained competitive advantage: a resource-based perspective, International Journal of Human Resource Management 5(2), pp.301-326. 
Youndt, M.; Subramaniam, M.; Snell, S. A.(2004), Intellectual capital profiles: An examination of investments and returns, Journal of Management Studies, 41(2), pp. 335-361.

Zahra, S.A. (1991). "Predictors and financial outcomes of corporate entrepreneurship: An exploratory study," Journal of Business Venturing, 6(4), 259-285.

Zahra, S.A., Ireland, R.D., Gutierrez, I. ve Hitt, M.A. (2000). Privatization and Entrepreneurial Transformation: Emerging Issues and a Future Research Agenda, Academy of Management Review, 25(3), 509-524.

Zahra, S.A., Nielsen, A.P., and Bogner, W.C., (1999). Corporate entrepreneurship, knowledge, and competence development, Entrepreneurship Theory Practice, 23 (3), 169-190.

Zander, U. and Kogut B.(1995), Knowledge and the speed of transfer and imitation of organizational abilities: an empirical test, Organization Science 6(1), pp.76-92.

Zott, C. (2003), Dynamic Capabilities and the Emergence of Intraindustry Differential Firm Performance: Insights from a Simulation Study, Strategic Management Journal, 24(2), pp. 97-125. 